\title{
Differences in iron requirements by concanavalin A-treated and anti- CD3-treated murine splenic lymphocytes
}

\author{
Solo R. Kuvibidila ${ }^{1}$, Maria Velez ${ }^{1}$, Lolie Yu ${ }^{1}$, Raj P. Warrier ${ }^{1}$ and B. Surendra Baliga ${ }^{2}$ \\ ${ }^{1}$ Louisiana State University, Department of Pediatrics, Divisions of Hematology/Oncology, 1542 Tulane Avenue, New \\ Orleans, LA 70112, USA \\ ${ }^{2}$ University of South Alabama College of Medicine, Department of Pediatrics, 2451 Fillingim Street, Mobile AL 36617, USA
}

(Received 4 July 2001 - Revised 10 January 2002 - Accepted 30 January 2002)

\begin{abstract}
Fe availability is critical for optimal lymphocyte proliferation; however, the minimum required levels are unknown. Such information is valuable when assessing in vitro immune responses in Fe-deficient subjects, because serum $(\mathrm{Fe})$ added to the culture medium may replete lymphocytes. To address this issue, splenic lymphocytes obtained from seventeen 3-month-old C57BL/6 mice were incubated without and with $1 \mathrm{mg} / \mathrm{l}$ concanavalin A or $50 \mu \mathrm{g} / \mathrm{l}$ anti-CD3 antibody in media that contained between 0.113 and $9.74 \mu \mathrm{mol} \mathrm{Fe} / \mathrm{l}$. Fe was provided by either fetal calf serum (FCS, 0-100 ml/l), newborn calf serum (NBCS, 0-100 ml/l), or NBCS $(10 \mathrm{ml} / \mathrm{l})$ plus ferric ammonium citrate. As expected, the rate of DNA synthesis increased with Fe levels $(P<0 \cdot 01)$. Maximum DNA synthesis was obtained with $2.26 \mu \mathrm{mol} \mathrm{Fe} / 1(50 \mathrm{ml}$ FCS/l) for concanavalin A and $0.895 \mu \mathrm{mol} / 1$ (20 ml FCS/l) for anti-CD3-treated cells. In serum-free media $(0.113 \mu \mathrm{mol} \mathrm{Fe} / \mathrm{l})$, the proliferative responses to concanavalin A were below the background, while they rose $5 \cdot 5$-fold in anti-CD3-treated cells $(P<0.05)$. In apotransferrin-supplemented media $(0 \cdot 13 \mu \mathrm{mol} \mathrm{Fe} / \mathrm{l})$, the proliferative responses to concanavalin $\mathrm{A}$ and anti-CD3 antibody were 18.6 and $71 \%$, respectively, of that obtained with $4.66 \mu \mathrm{mol} \mathrm{Fe} / \mathrm{l}$ $(100 \mathrm{ml} \mathrm{FCS} / \mathrm{l})$. Interleukin 2 secretion also followed the same trend as lymphocyte proliferation. Since differences between both mitogens persisted after FCS was substituted with NBCS, we can rule out an effect on ribonucleotide reductase activity, or by other serum growth factors. We speculate an Fe effect at an early step of T-cell activation. Data suggest that the minimum $\mathrm{Fe}$ concentration required for lymphocyte proliferation varies with the mitogen.
\end{abstract}

Iron: Lymphocyte proliferation: Concanavalin A: Anti-C antibody: Interleukin 2

It has been established that Fe plays crucial roles on many cellular functions and it is also required for proliferation of all cells, specifically lymphocytes (Mainou-Fowler \& Brock, 1985; Cazzola et al. 1990; Brock, 1992). Peripheral $\mathrm{T}$ cells from healthy individuals as well as leukaemic cell lines fail to proliferate when they are incubated in serumfree and transferrin-free media (Mainou-Fowler \& Brock, 1985; Cazzola et al. 1990; Haq et al. 1995). In fact they undergo apoptosis (Haq et al. 1995). Antigen and mitogen-treated $\mathrm{T}$ lymphocytes show an increase in transferrin receptor molecules to ensure sufficient Fe uptake from culture media to satisfy the increased demand of proliferating cells (Cazzola et al. 1990). The role of Fe in T-lymphocyte proliferation is in part due to the fact that this trace element is a cofactor of ribonucleotide reductase, the enzyme that reduces ribonucleosides to deoxyribonucleosides, which are later converted to deoxyribonucleotides. This enzyme has a rapid turnover and therefore Fe must be supplied continuously in order to sustain DNA synthesis and cell proliferation (Thelander et al. 1983; Furakawa et al. 1992).

In lymphocytes cultured in vitro, Fe is usually supplied in the form of fetal calf serum (FCS), bovine serum, newborn calf serum (NBCS), or human $A B$ serum at a final concentration of $100 \mathrm{ml} / \mathrm{l}$. However, the minimum concentrations of either Fe or serum required by murine splenic lymphocytes activated by different mitogens is unknown. Such information is valuable especially when studying the effects of Fe deficiency in human subjects and laboratory animals on in vitro lymphocyte proliferation and other functions. A high serum concentration may replete Fe-deficient cells

Abbreviations: BSA, bovine serum albumin; Con A, concanovalin A; FCS, fetal calf serum; IL, interleukin; NBCS, newborn calf serum.

* Corresponding author: Dr Solo R. Kuvibidila, fax +1 504568 3078, email skuvib@LSUHSC.edu 
in vitro and thus mask the differences between Fe-normal and Fe-deficient cells. A very low concentration of serum will reduce $\mathrm{Fe}$ concentration in the culture medium and reduce the rate of DNA synthesis even of the Fe-normal cells, thus leading to negative results. In the present study, we determined whether there are differences in the requirement for $\mathrm{Fe}$ and/or serum by normal murine splenic lymphocytes that are activated by concanavalin A (Con A) and anti-CD3 antibody.

\section{Materials and methods}

\section{Materials}

Reagents were received from the following sources: Sigma (St Louis, MO, USA) apotransferrin, Con A, $\beta$-mercaptoethanol, Drabkin's reagent, ferric ammonium citrate, haemoglobin standard, Fe assay kits, bovine serum albumin (BSA); GIBCO (Grand Island, NY, USA) RPMI1640 with $25 \mathrm{~mm}$-HEPES, FCS, NBCS, nonessential amino acids, sodium pyruvate, penicillin-streptomycin; Bio-Whittaker (Walkersville, MD, USA) L-glutamine; Harlan Teklad (Madison, WI, USA) the AIN-76 diet that contained $0.895 \mathrm{mmol} \mathrm{Fe} / \mathrm{kg}$ (ferrous sulfate); NEN Dupont (Boston, MA, USA) $\left[{ }^{3} \mathrm{H}\right]$-thymidine $(247.9 \mathrm{GBq} /$ mmol); ICN (Costa Mesa, CA, USA) Cytoscint; PharMingen (Costa Mesa, CA, USA) anti-CD3 antibody; R \& D Systems (Minneapolis, MN, USA) interleukin (IL) 2 assay kits.

\section{Evaluation of iron status at the end of the feeding period}

Seventeen 6-week-old C57BL/6 female mice were purchased from Charles River Breeding Laboratories (Wilmington, MA, USA). Two to three mice were housed per microisolator system cage, which was fitted with a filter. The cages were sterile. Mice had free access to their feeds and sterile deionized water for 2 months. The vivarium temperature was set at $22^{\circ} \mathrm{C}$, with a $12 \mathrm{~h}$ light-dark cycle. At the time of killing, mice were anesthaetized by diethyl ether inhalation for 30-60 s. After blood was drawn from the retro-orbital plexus, they were killed by cervical dislocation. Haemoglobin and packed cell volume were measured by the cyanmethaemoglobin method and centrifugation respectively. The livers were removed, weighed and immediately frozen at $-40{ }^{\circ} \mathrm{C}$ until used for $\mathrm{Fe}$ assay. Liver homogenates were prepared as we reported previously (Kuvibidila et al. 1998). Fe concentration in each supernatant fraction was assayed by colorimetric method using a kit that was purchased from Sigma (catalogue no. 565). Briefly, $250 \mu \mathrm{l}$ liver Fe extract or Fe-free distilled deionized water was mixed with $2.5 \mathrm{ml} \mathrm{Fe}$ buffer reagent in a plastic cuvette. The background optical density was read (determined in a Beckman DU-64 spectrophotometer; Fullerton, CA, USA) set at a wavelength of $560 \mathrm{~nm}$. After $50 \mu \mathrm{l}$ colour reagent (ferrozine) was added to each cuvette and mixed for $10 \mathrm{~s}$ by a vortex mixer, samples were incubated at $37^{\circ} \mathrm{C}$ in a water-bath for $10 \mathrm{~min}$. Cuvettes were vortexed again for $10 \mathrm{~s}$ and the final optical density was determined at the same wavelength as for the initial reading. The Fe concentrations were calculated by the following formula: Fe concentration $(\mu \mathrm{g} / \mathrm{l})=(($ sample final optical density - sample initial optical density)/(standard final optical density - standard initial optical density) $\times 5000$, where $5000 \mu \mathrm{g} / \mathrm{l}$ is the Fe concentration of the standard. All assays were done in duplicate.

\section{Preparation of spleen cell suspension}

After spleens were removed under sterile conditions, single-cell suspensions were prepared by standard techniques in serum-free RPMI-1640 wash medium that was supplemented with $10 \mathrm{~g} \mathrm{BSA} / 1,50 \mathrm{mg}$ streptomycin/l and $5 \times 10^{4}$ units penicillin/l. This medium contained $0 \cdot 113 \mu \mathrm{mol} \mathrm{Fe} / \mathrm{l}$. Cells were washed at $400 \mathrm{~g}$ at $4{ }^{\circ} \mathrm{C}$ for $10 \mathrm{~min}$. The supernatant fraction was decanted and the pellets were resuspended in $1 \mathrm{ml}$ ice-cold sterile deionized water to lyse erythrocytes. Cells were further washed twice under the same conditions. The pellets were then resuspended in $2 \mathrm{ml}$ wash medium. Total and viable cells were counted using a haemocytometer under a light microscope after cells were diluted in a solution of Trypan Blue $(4 \mathrm{~g} / \mathrm{l})$.

\section{Lymphocyte proliferation}

Viable cells $\left(1 \times 10^{6}\right)$ were mixed with either $1 \mathrm{mg}$ Con A/l or $50 \mu \mathrm{g}$ anti-CD3 antibody/l. These concentrations were the optimal levels based on mitogen dose responses that were performed in preliminary experiments. For background DNA synthesis, culture medium was added to cells instead of the mitogen. The culture media were composed of RPMI-1640, $50 \mathrm{mg}$ streptomycin/l, $5 \times 10^{4}$ units penicillin/l, $2 \mathrm{~mm}$-L-glutamine, $1 \mathrm{~mm}$-sodium pyruvate, $0 \cdot 1 \mathrm{~mm}$-nonessential amino acids and $50 \mu \mathrm{M}-\beta$-mercaptoethanol. FCS was added at the following concentrations: $0,10,20,50$ and $100 \mathrm{ml} / \mathrm{l}$. The $\mathrm{Fe}$ concentrations of these culture media were $0.113,0.450,0.895,2.260$ and $4.660 \mu \mathrm{mol} / 1 \mathrm{respectively.} \mathrm{In} \mathrm{some} \mathrm{experiments,} 25 \mathrm{mg}$ apotransferrin/1, 10, 20, 50 or $100 \mathrm{ml} \mathrm{NBCS/1}$ were added to the culture media instead of FCS. The Fe concentrations of the apotransferrin and NBCS-supplemented media were: $0.130,0.201,0.403,0.806$ and $1.925 \mu \mathrm{mol} / \mathrm{l}$. In another subgroup of mice ( $n$ 5), ferric ammonium citrate was added to the culture medium that contained $0.201 \mu \mathrm{mol}$ $\mathrm{Fe} / \mathrm{l}$ in the form of $\mathrm{NBCS}(10 \mathrm{ml} / \mathrm{l})$. The final concentrations of $\mathrm{Fe}$ were $2 \cdot 100,4.975$, and $9.740 \mu \mathrm{mol} / \mathrm{l}$. Mitogen stimulated and unstimulated cells were incubated at $37^{\circ} \mathrm{C}, 5 \% \quad \mathrm{CO}_{2}$ in a humidified NAPCO incubator (Model 5100; Portland, OR, USA) for $48 \mathrm{~h}$ before being pulsed with $37 \mathrm{kBq}\left[{ }^{3} \mathrm{H}\right]$ thymidine per $2 \times 10^{5}$ cells. After $24 \mathrm{~h}$, the cultures were harvested (PHD Cell Harvester; Cambridge Technology, Watertown, MA, USA). Each filter was transferred to a scintillation vial that contained $2 \mathrm{ml}$ Cytoscint (ICN). The radioactivity incorporated into DNA was measured by counting each sample for $1 \mathrm{~min}$ in an LKB liquid scintillation counter (Model 1219; Turku, Finland). 

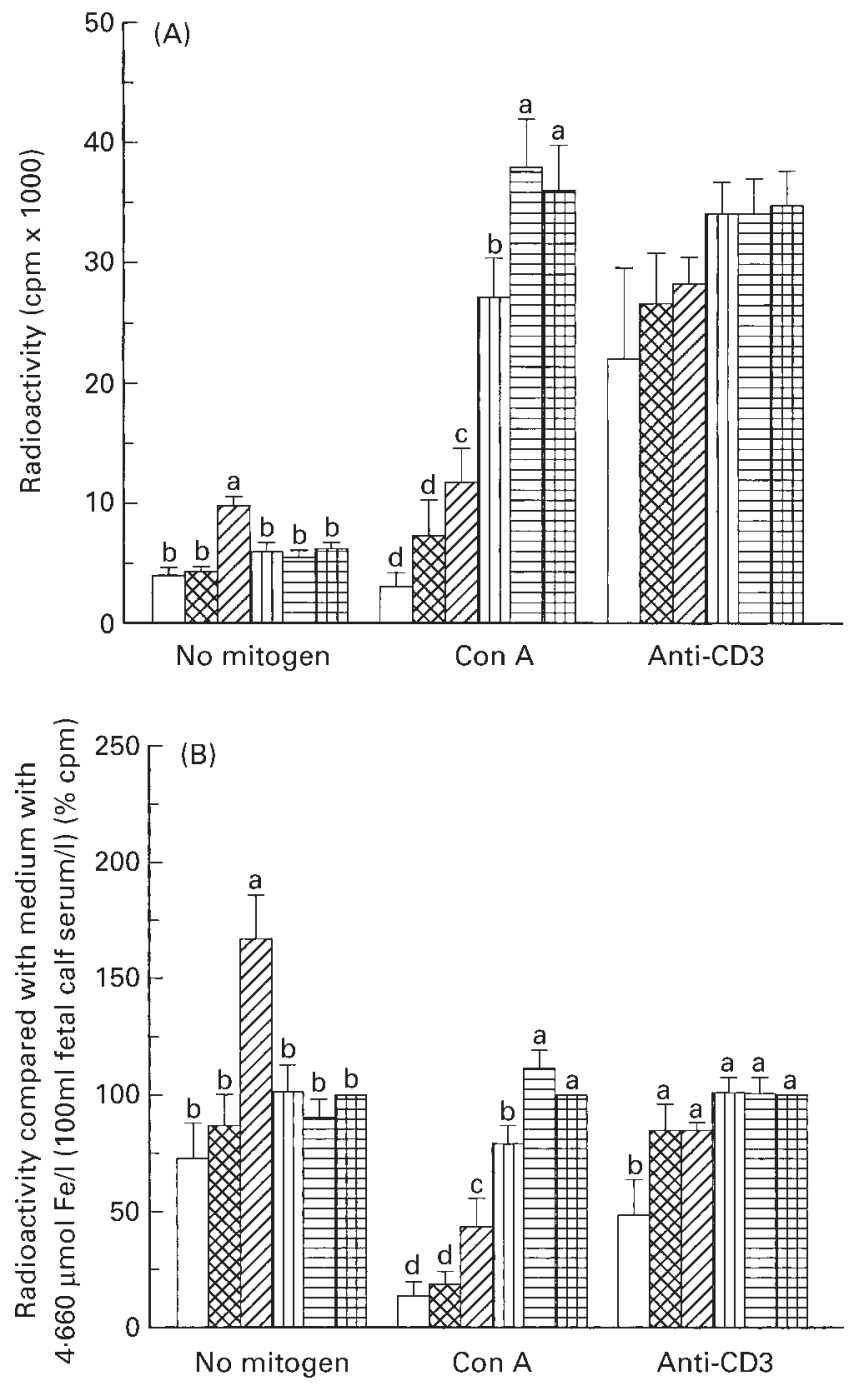

Fig. 1. Effects of iron and fetal calf serum concentrations on splenic lymphocyte proliferation. For details of procedures, see p. 68. Con A, concanavalin A, $\square, 0.113 \mu \mathrm{mol} \mathrm{Fe} / \mathrm{l} ; \quad 0.130 \mu \mathrm{mol} \mathrm{Fe} / \mathrm{l} ;$, $0.450 \mu \mathrm{mol} \mathrm{Fe} / \mathrm{l}$; 皿, $0.895 \mu \mathrm{mol} \mathrm{fe} / \mathrm{l}$; 目, $2.260 \mu \mathrm{mol} \mathrm{Fe} / \mathrm{l}$; 囲, $4.660 \mu \mathrm{mol} \mathrm{Fe} / \mathrm{l}$. The corresponding fetal calf serum concentrations are: $0 \mathrm{ml} / \mathrm{l}$ (bovine serum albumin added to medium), $0 \mathrm{ml} / \mathrm{l}$ (apotransferrin added to medium), $10,20,50$ and $100 \mathrm{ml}$ fetal calf serum/l for $0.113,0.130,0.450,0.895,2.260$ and $4.66 \mu \mathrm{mol} \mathrm{Fe} / \mathrm{l}$ respectively. Values are means for seventeen mice with standard errors shown by vertical bars. ${ }^{a, b, c, d}$ Mean values for the same mitogen treatment with unlike superscript letters were significantly different $(P<0.05)$. cpm, counts per minute.

\section{Measurement of interleukin 2}

Macrocultures that contained $1 \times 10^{6}$ viable spleen cells $/ \mathrm{ml}$ were incubated without or with $1 \mathrm{mg}$ Con $\mathrm{A} / 1$ or $50 \mu \mathrm{g}$ anti$\mathrm{CD} 3 / 1$ for $48 \mathrm{~h}$ in culture media that contained $0 \cdot 130$ $4.660 \mu \mathrm{mol} \mathrm{Fe} / \mathrm{l}$ supplemented in the form of FCS. Cultures were incubated in $12 \times 75$ culture tubes at $37^{\circ} \mathrm{C}, 5 \% \mathrm{CO}_{2}$ in a humidified atmosphere. At the end of the incubation period, tubes were centrifuged at $4{ }^{\circ} \mathrm{C}$, $670 \mathrm{~g}$ for $10 \mathrm{~min}$. Supernatant fractions were divided into subsamples and frozen at $-40^{\circ} \mathrm{C}$ until IL-2 was assayed by enzyme immunoassay with kits that were purchased from R \& D Systems. Instructions provided by the vendor were carefully followed. A standard curve was included in each experiment and the assay was performed in duplicate. The minimum detection level was $15.6 \mathrm{pg} / \mathrm{ml}$.

\section{Calculations and statistical analysis}

Descriptive statistics (mean values with their standard errors) and ANOVA were calculated by the use of Microstatistical program (Ecosoft Inc., Indianapolis, IN, USA) and as described in the literature (Munro, 1993). When ANOVA showed that there were significant differences between culture media, Scheffé's test was used to compare means of two media at a time. The level of significance was set at $P<0.05$

\section{Results}

The mean concentrations of haemoglobin (146.6 (SEM 4.822) $\mathrm{g} / \mathrm{l}$ ), liver $\mathrm{Fe}$ stores (1.03 (SEM 0.082) $\mu \mathrm{mol} / \mathrm{g}$ liver), packed cell volume (49.6 (SEM 0.49) \%), and body weight $(20 \cdot 0$ (SEM $0 \cdot 359) \mathrm{g}$ ) were within the range found in normal mice in our laboratory (Kuvibidila et al. 1998). As one would expect, the rate of DNA synthesis of splenic lymphocytes increased with $\mathrm{Fe}$ or FCS concentrations (Fig. 1(A) and (B)). $\left[{ }^{3} \mathrm{H}\right]$ Thymidine incorporation into DNA of non-activated cells was not different between cultures that were incubated in BSA- and apotransferrin-supplemented media. However, the addition of $\mathrm{Fe}$ in the form of FCS resulted in a significant increase in the rate of background DNA synthesis, which reached a peak at $0.450 \mu \mathrm{mol} / 1(10 \mathrm{ml} \mathrm{FCS} / \mathrm{l})$, but decreased at higher concentrations $(P<0 \cdot 05)$.

In mitogen-treated cells, the rate of DNA synthesis significantly increased with $\mathrm{Fe}$ and FCS concentrations (Fig. 1(A) and (B), $P<0 \cdot 05$ ). However, the pattern of proliferative responses to Con A-treated cells was different from that of anti-CD3 treated cells. The maximum rate of DNA synthesis was obtained at $2.260 \mu \mathrm{mol} \mathrm{Fe} / 1(50 \mathrm{ml}$ FCS/l) and $0.895 \mu \mathrm{mol} \mathrm{Fe} / \mathrm{l}(20 \mathrm{ml} \mathrm{FCS} / \mathrm{l})$ for Con A-treated and anti-CD3 treated spleen cells respectively. In serum-free BSA-supplemented medium that contained $0.113 \mu \mathrm{mol} \mathrm{Fe} / 1,\left[{ }^{3} \mathrm{H}\right]$ thymidine incorporation into DNA of Con A-treated cells was reduced by $24 \%$ compared with the background $(P>0.05)$, and it was only $13.7 \%$ of that obtained with $4.660 \mu \mathrm{mol} \mathrm{Fe} / \mathrm{l}(100 \mathrm{ml}$ FCS/l) $(P<0.05$; Fig. 1(B)). When apotransferrin was added to the BSA-supplemented medium thus increasing the $\mathrm{Fe}$ levels to $0.13 \mu \mathrm{mol} / \mathrm{l}$, the proliferative response to Con A rose to $18.6 \%$ of that obtained with $4.660 \mu \mathrm{mol} \mathrm{Fe} / 1$ $(100 \mathrm{ml} \mathrm{FCS} / \mathrm{l})$. The slight increase in the rate of DNA synthesis was very likely to be due to improved absorption of residual Fe by apotransferrin. In anti-CD3 treated cells, the absence of serum and apotransferrin did not inhibit DNA synthesis compared with the background. In fact, the proliferative response rose by 5.5 -fold $(P<0.001)$ and it was $48.6 \%$ of the response obtained with $4.660 \mu \mathrm{mol} \mathrm{Fe} / \mathrm{l}$ or $100 \mathrm{ml} \mathrm{FCS} / 1$ (Fig. 1(B)). Apotransferrin significantly increased the proliferative responses to anti-CD3 $(P<0.05)$ to the point that they were $71 \%$ of the maximum. When the medium contained $0.895 \mu \mathrm{mol} \mathrm{Fe} / \mathrm{l}$, $\left[{ }^{3} \mathrm{H}\right]$ thymidine uptake by anti-CD3 treated cells was 


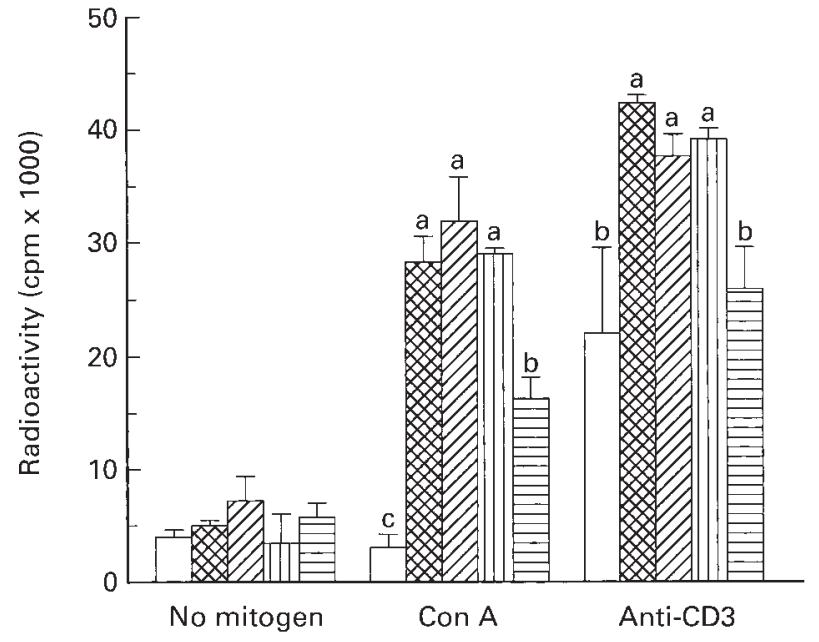

Fig. 2. Effects of iron concentrations added to the culture medium in the form of newborn calf serum on the rate of DNA synthesis in concanavalin $\mathrm{A}$ (Con $\mathrm{A}$ ) and anti-CD3 treated cells. For details of procedures, see p. 68. $\square, 0.113 \mu \mathrm{M}-\mathrm{Fe}$; $0.130 \mu \mathrm{mol} \mathrm{Fe} / \mathrm{l} ; \mathbb{Z}$,

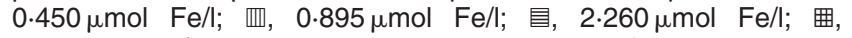
$4.66 \mu \mathrm{mol} \mathrm{Fe} / \mathrm{l}$. The corresponding newborn calf serum concentrations for different iron levels were: $0,10,20,50$ and $100 \mathrm{ml}$ newborn calf serum/l for $0.113,0.201,0.403,0.806,1.925 \mu \mathrm{mol} \mathrm{Fe} / \mathrm{l}$ respectively. Values are means for five mice with standard errors shown by vertical bars. ${ }^{a, b, c}$ Mean values for both Con $A$ and antiCD3 with unlike superscript letters were significantly different $(P<0.05)$. cpm, counts per minute.

$101 \%$ of the maximum obtained with $4.660 \mu \mathrm{mol} / 1$ whereas it was less than $80 \%$ for Con A-treated cells (Fig. 1(B)).

When FCS was replaced by NBCS, the responses to Con A and anti-CD3 followed the same trend as those of cultures that were incubated in FCS-supplemented medium (Fig. 2). For example, there was a $13 \%$ increase in Con A proliferative responses of spleen cells when $20 \mathrm{ml}$ NBCS/l $(0.403 \mu \mathrm{mol} \mathrm{Fe} / \mathrm{l})$ was added to the culture media instead of $10 \mathrm{ml} \mathrm{NBCS/1}(0.201 \mu \mathrm{mol} \mathrm{Fe} / \mathrm{l})$. In anti-CD3-treated cultures, the proliferative responses did not increase, in fact they decreased by $11 \%(P>0.05)$. The addition of different concentrations of ferric ammonium citrate to the culture medium that was supplemented with $10 \mathrm{ml} \mathrm{NBCS/1}$ resulted in 36-40\% increase of the proliferative responses to Con A, whereas it resulted in a $4-20 \%$ decrease in the responses to antiCD3 (Fig. 3, $P<0.05$ ).

Similar to the results of cell proliferation, IL-2 secretion was also affected by the concentration of Fe or FCS in mitogen-treated and untreated cultures (Fig. 4). In non-activated cells, IL-2 secretion was very low in apotransferrinsupplemented medium, rose upon addition of $\mathrm{Fe}$ in the form of FCS to culture media and reached a peak at $2.260 \mu \mathrm{mol} \mathrm{Fe} / 1$ (50 ml FCS/l). In Con A-treated cells, there was a steady rise in IL-2 secretion with the increase in Fe and FCS levels from less than $50 \mathrm{pg} / \mathrm{ml}$ in apotransferrin-supplemented medium to about $200 \mathrm{pg} / \mathrm{ml}$ in $4.660 \mu \mathrm{mol} \quad \mathrm{Fe} / \mathrm{l} \quad(100 \mathrm{ml} \quad \mathrm{FCS} / \mathrm{l})$-containing medium $(P<0 \cdot 05)$. In anti-CD3 activated spleen cells, the addition of $0.450 \mu \mathrm{mol} \mathrm{Fe} / 1(10 \mathrm{ml} \mathrm{FCS} / \mathrm{l})$ to the culture medium slightly increased IL-2 secretion when compared with apotransferrin-supplemented medium. However, at

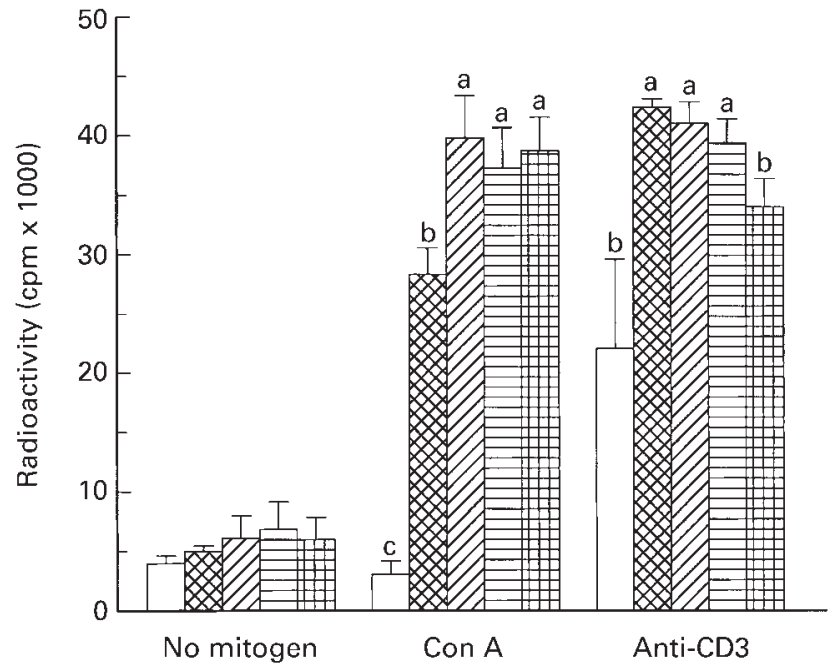

Fig. 3. Effects of iron concentrations added to the culture medium that contained newborn calf serum $(10 \mathrm{ml} / \mathrm{l})$ on the rate of DNA synthesis in mitogen treated and untreated spleen cells. For details of procedures, see p. 68, Con A, concanavalin A, $\square, 0.113 \mu \mathrm{mol} \mathrm{Fe/l;}$ 冈, $0.201 \mu \mathrm{mol} \mathrm{Fe} / \mathrm{l} ;$ 四, $2.10 \mu \mathrm{mol} \mathrm{Fe} / \mathrm{l}$; 目, $4.975 \mu \mathrm{mol} \mathrm{Fe} / \mathrm{l}$; 囲, $9.74 \mu \mathrm{mol}$ Fe/l. Values are means for five mice with standard errors shown by vertical bars. ${ }^{a, b}$ Mean values for each mitogen with unlike superscript letters were significantly different $(P<0.05)$. $\mathrm{cpm}$, counts per minute.

$0.895 \mu \mathrm{mol} \mathrm{Fe} / 1$, IL-2 levels decreased. In fact at $2 \cdot 260$ and $4.660 \mu \mathrm{mol} F / 1$, IL-2 secretion decreased below the baseline levels that were obtained in apotransferrin-supplemented media, although the reduction was not significant.

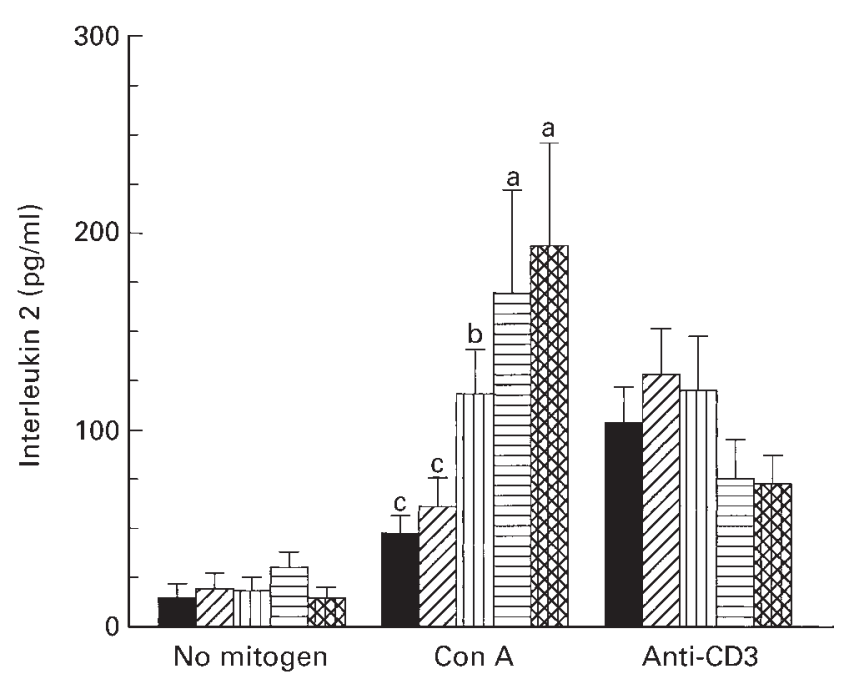

Fig. 4. Effects of iron concentrations added to culture medium in the form of fetal calf serum on interleukin 2 secretion by activated and non-activated murine spleen cells. For details of procedures, see p. 68. Con A, concanavalin A. 口, $0.130 \mu \mathrm{mol} \mathrm{Fe/l;}$ $0.450 \mu \mathrm{mol} F e / l$; 四, $0.895 \mu \mathrm{mol} \mathrm{Fe} / \mathrm{l}$; 自, $2.260 \mu \mathrm{mol} \mathrm{Fe} / \mathrm{l}$; $4.660 \mu \mathrm{mol}$ Fe/l. Values are means for twelve mice with standard errors shown by vertical bars. The corresponding fetal calf serum concentrations for listed iron levels are: 0 (25 mg apotransferrin/l), $10,20,50,100 \mathrm{ml}$ fetal calf serum/l for $0.130,0.450,0.895,2.260$, $4.660 \mu \mathrm{mol} F e / /$ respectively. ${ }^{a, b, c}$ Mean values with unlike superscript letters for Con $A$ were significantly different $(P<0.05)$. No significant differences were observed between the five iron concentrations in anti-CD3 treated cultures. 


\section{Discussion}

The importance of Fe-transferrin on proliferation and functions of activated human as well as laboratory animal lymphocytes has been established (Brock, 1981; Lederman et al. 1984; Golding \& Young, 1995). Most, though not all, clinical and animal studies have shown that $\mathrm{Fe}$ deficiency reduces in vitro lymphocyte proliferative responses to mitogens and antigens (for review see Brock, 1992; Thibault et al. 1993; Omar \& Blakley, 1994; Kuvibidila et al. 1998). The lack of reduction in lymphocyte proliferation in the few studies is puzzling. Although the severity of $\mathrm{Fe}$ deficiency, differences in methods, and unknown confounding variables in the control group are thought to be the cause of the negative results, our present results may provide one other explanation. It seems that the type of stimulant used may be a key factor that determines the extent of impairment of lymphocyte proliferation and likely other immune responses during Fe deficiency.

The present study suggests that there are differences in the sensitivity to Fe and/or FCS concentrations of normal murine spleen cells incubated with either Con A or antiCD3 antibody. Con A is a non-specific T-cell mitogen that binds to T cells as well as non-T cells through glucosyl and mannosyl receptors (Nagase et al. 1998). In contrast, anti-CD3 antibody is specific and binds only to the T-cell receptor (T-cell receptor-CD3 complex) (Abbas et al. 1997a). One of the main functions of $\mathrm{Fe}$ is to maintain the activity of ribonucleotide reductase, the enzyme that is responsible for the biosynthesis of deoxyribonucleotides (Hoffbrand et al. 1976; Thelander et al. 1983). This is a rate-limiting step in the pathways that lead to mitosis. It was surprising to find that the absence of serum and apotransferrin inhibited the rate of DNA synthesis by $24 \%$ in Con A-treated cells, whereas that had no negative effect in anti-CD3 treated cells. Our results on anti-CD3 treated cells are similar to those of Golding \& Young (1995), who observed that normal human peripheral blood lymphocytes incubated in serum-free medium in the presence of phytohaemagglutin could proliferate to a certain degree. However, the addition of either human serum, FCS or Fe-transferrin was required for optimal cell proliferation. Unfortunately, these authors did not provide results from non-activated cells and they only studied one mitogen.

In our present study, differences in the sensitivity of murine spleen cells to Con A and anti-CD3 antibody were unlikely to be due to a growth factor (other than $\mathrm{Fe}$ ) in the serum since when ferric ammonium citrate was added to medium supplemented with $10 \mathrm{ml} \mathrm{NBCS} / 1$, the differences between both mitogens persisted. The differential sensitivity of Con A $v$. anti-CD3 treated cells may also not be at the level of ribonucleotide reductase, but probably at an early step in T-cell activation pathways, such as mitogen binding to specific receptors, hydrolysis of cell membrane phospholipids, activation of protein kinase $\mathrm{C}$ and other protein kinases, or cytokine secretion. In support of this speculation is, first, the pattern of IL-2 secretion in Con A and anti-CD3 treated cells (Fig. 4). In apotransferrin-supplemented media, anti-CD3 treated cells secreted a mean of $103.0 \mathrm{pg}$ IL-2/ml compared with $47.3 \mathrm{pg} / \mathrm{ml}$ for Con A-treated cells. The addition of 0.450 and $0.895 \mu \mathrm{mol} \mathrm{Fe} / 1$ (10 and $20 \mathrm{ml} \mathrm{FCS} / 1$ respectively) only slightly increased IL-2 secreted by anti-CD3 treated cells, whereas it resulted in a 4-fold increase in Con A-treated cells. Second, in one experiment, we observed that the binding of Con A conjugated to fluorescein isothiocyanate was significantly decreased by approximately $90 \%$ when $100 \mathrm{ml} \mathrm{FCS/l}$ was added to the incubation medium (SR Kuvibidila and LE Leiva, unpublished results). We therefore speculate that in serum-free media and low serum levels, spleen cells bind more Con A, whereas the opposite is observed when the medium is supplemented with $100 \mathrm{ml} \mathrm{FCS/l}$. Since high levels of Con A are toxic to lymphoid as well as nonlymphoid cells, we speculate that many Con A-treated cells, incubated in low-serum medium, die (Nagase et al. 1988). Third, the activity and mRNA levels of protein kinase C (Phillips et al. 1987; Alcantara et al. 1994; Kuvibidila et al. 1999) and certain cyclin (D type)dependent kinases (Gao \& Richardson, 2001) are significantly reduced by $\mathrm{Fe}$ chelation. These protein kinases are involved in signal transduction in the early phase of T-lymphocyte activation, prior to DNA synthesis and mitosis. However, it is unknown whether anti-CD3 antibody activates these kinases more efficiently than Con A.

IL-2 secretion, however, may not be the only cytokine involved in lymphocyte proliferation affected by different levels of iron in the culture medium. Scaccabarozzi et al. (2000) have recently shown that Fe chelation by desferrioxamine significantly reduced the secretion of tumour necrosis factor $\alpha$ by activated human monocytic THP-1 cells. Tumour necrosis factor $\alpha$ modulates the translocation of nuclear factor- $\kappa \mathrm{B}$ from the cytoplasm to the nucleus, where it binds to specific DNA sequences and initiates the expression of several cytokine inducible genes including IL-2 and IL-2 receptor (Abbas et al. $1997 b, c)$. This cascade of events leads to lymphocyte proliferation. No information is available on the role of $\mathrm{Fe}$ on the translocation of nuclear factor-кB. Whatever the mechanism involved in the differential $\mathrm{Fe}$ requirements by anti-CD3 and Con A-treated spleen cells for proliferation, our results provide one of the clues that may explain the normal lymphocyte proliferation occasionally reported in Fe-deficient human subjects and laboratory animals (Gross et al. 1975; Galan et al. 1992). Our results imply that an Fe-deficient individual may have either impaired or (nearly) normal lymphocyte proliferative responses depending on whether the stimulant primarily interacts with the $\mathrm{T}$-cell receptor-CD3 complex or the glucosyl-mannosyl receptors (similar to those used by Con A).

In summary, our present results suggest that the minimum levels of Fe required by murine splenic lymphocytes and perhaps human lymphocytes for proliferation vary with the type of mitogen. We are unaware of a similar previous observation made by other investigators. Further experiments are required to determine which early events in the T-cell activation pathways, other than IL-2, are less affected by Fe levels in anti-CD3 treated spleen cells compared with Con A-activated lymphocytes. 


\section{Acknowledgements}

We thank Carole Lachney for her technical assistance during the preparation of this manuscript. This work was supported by National Institutes of Health grant no. HL03144 and a special grant from the Dean of the Medical School, LSU Health Sciences Center in New Orleans.

\section{References}

Abbas AK, Lichtman AH \& Pober JS (1997a) T cell maturation in the thymus. In Cellular and Molecular Immunology, pp. 171-193 [AK Abbas, AH Lichman and JS Pober, editors]. Philadelphia, PA: W.B. Saunder Company.

Abbas AK, Lichtman AH \& Pober JS (1997b) Maturation of B lymphocytes and expression of immunoglobulin genes. In Cellular and Molecular Immunology, pp. 66-95 [AK Abbas, AH Lichtman and JS Pober, editors]. Philadelphia, PA: W.B. Saunder Company.

Abbas AK, Lichtman AH \& Pober JS (1997c) T cell antigen recognition and activation. In Cellular and Molecular Immunology, pp. 139-170 [AK Abbas, AH Lichtman and JS Pober, editors]. Philadelphia, PA: W.B. Saunder Company.

Alcantara O, Obeid L, Hannun Y, Ponka P \& Boldt DH (1994) Regulation of protein kinase $\mathrm{C}$ (PKC) expression by iron: effect of different iron compounds on PKC-beta and PKCalpha gene expression and the role of the $5^{\prime}$-flanking region of the PKC-beta gene in the response to ferric transferrin. Blood 84, 3510-3517.

Brock HJ (1981) The effect of iron and transferrin on the response of serum-free cultures of mouse lymphocytes to concanavalin and lipopolysaccharides. Immunology 43, 387-392.

Brock HJ (1992) Iron and the immune system. In Iron and Human Disease, pp. 161-178 [RB Lauffer, editor]. Boca Raton, FL: CRC Press.

Cazzola M, Bergamaschi G, Dezza L \& Arosio P (1990) Manipulation of cellular iron metabolism for modulating normal and malignant cell proliferation: achievements and prospects. Blood 75, 1903-1919.

Furukawa T, Naitoh Y, Kohno H, Tokinaga R \& Taketani S (1992) Iron deprivation decreases ribonucleotide reductase and DNA synthesis. Life Sciences 50, 2059-2065.

Galan P, Thibault H, Preziosi P \& Herceberg S (1992) Interleukin-2 production in iron-deficient children. Biological Trace Element Research 32, 421-426.

Gao J \& Richardson DR (2001) The potential of iron chelators of the pyridoxal isonicotinoyl hydrazone class as effective antiproliferative agents. IV: the mechanisms involved in inhibiting cell-cycle progression. Blood 98, 842-850.

Golding S \& Young SP (1995) Iron requirements of human lymphocytes: relative contribution of intra- and extra-cellular iron. Scandinavian Journal of Immunology 41, 229-236.
Gross RL, Reid JVO, Newberne PM, Burgess B, Marston R \& Hift W (1975) Depressed cell-mediated immunity in megaloblastic anemia due to folic acid deficiency. American Journal of Clinical Nutrition 28, 225-232.

Haq RU, Wereley JP \& Chitambar CR (1995) Induction of apoptosis by iron deprivation in human leukemic CCRF-CEM cells. Experimental Hematology 23, 428-432.

Hoffbrand AV, Ganeshaguru K, Hooton JWL \& Tattersall MHN (1976) Effect of iron deficiency and desferrioxamine on DNA synthesis. British Journal of Haematology 33, 517-526.

Kuvibidila SR, Baliga BS, Warrier RP \& Suskind RM (1998) Iron deficiency reduces the hydrolysis of cell membrane phosphatidyl-inositol 4,5 bisphosphate during splenic lymphocyte activation in C57BL/6 mice. Journal of Nutrition 128, 1077-1083.

Kuvibidila SR, Kitchens D \& Baliga BS (1999) In vivo and in vitro iron deficiency reduces protein kinase $\mathrm{C}$ activity and translocation in murine splenic and purified $\mathrm{T}$ cells. Journal of Cellular Biochemistry 74, 468-478.

Lederman HM, Cohen A, Lee JWW, Freedman MH \& Gelfand EW (1984) Deferoxamine: a reversible S-phase inhibitor of human lymphocyte proliferation. Blood 64, 748-753.

Mainou-Fowler T \& Brock JH (1985) Effect of iron deficiency on the response of mouse lymphocytes to concanavalin A: the importance of transferrin-bound iron. Immunology 54, $325-332$.

Munro HB (1993) Differences among group means: one-way analysis of variance. In Statistical Methods for Health Care Research, 2nd ed., pp. 99-128 [HB Munro and EB Page, editors]. Philadelphia, PA: J.B. Lippincott Company.

Nagase F, Abo T, Hiramatsu K, Suzuki S, Du J \& Nakashima I (1998) Induction of apoptosis and tyrosine phosphorylation of cellular proteins in T cells and non-T cells by stimulation with concanavalin A. Microbiology and Immunology 42, 567-574.

Omar FO \& Blakley BR (1994) The effects of iron deficiency and iron overload on cell-mediated immunity in the mouse. British Journal of Nutrition 72, 899-909.

Phillips JL, Bodt DH \& Harper J (1987) Iron-transferrin-induced increase in protein kinase $\mathrm{C}$ activity in CCRF-CEM cells. Journal of Cellular Physiology 132, 349-353.

Scaccabarozzi A, Arosio P, Weiss G, Valenti L, Dongiovanni P, Fracanzani AL, Mattioli M, Levi S, Fiorelli G \& Fargion S (2000) Relationship between TNF- $\alpha$ and iron metabolism in differentiating human monocytic THP-1 cells. British Journal of Haematology 110, 978-984.

Thelander L, Graslund A \& Thelander M (1983) Continual presence of oxygen and iron required for mammalian ribonucleotide reduction. Possible regulation mechanism. Biochemical and Biophysical Research Communications 110, 859-865.

Thibault H, Galan P, Selz F, Preziosi P, Olivier C, Badoual J \& Hercberg S (1993) The immune response in iron-deficient young children: effect of iron supplementation on cell-mediated immunity. European Journal of Pediatrics 152, 120-124. 